\title{
A 85 mm-es 1939M 52K 8,5/8,8 Flak 39(r) közepes légvédelmi ágyú magyarországi alkalmazása
}

A szovjet 1939M 85 mm-es (52 K) löveg fejlesztése az I. világháborúig nyúlik vissza. A cári orosz hadsereg már 1915-ben, a korábbi 1904M 76 mm-es löveg átalakításával, a németekéhez hasonló, gépkocsira telepített, magasított talpra szerelt, $360^{\circ}$-ban körbeforgatható légvédelmi ágyút fejlesztett. E löveg alapján 1931-re készítették el M. Ny. Loginov ${ }^{1}$ orosz mérnök vezetésével a 31M 76 mm-es légvédelmi ágyút. Ennek az ágyúnak jellegzetes egytengelyes, levehető futóműves, bonyolult módon öszszecsukható alsó talpa volt. 1938-ban a 36M 4 cm-es

1. ábra. Löveg átbillentése a gyakorlótéri tüzelöállásban 1948-1950 (Fotó: HM HIM, MNN1041-11)

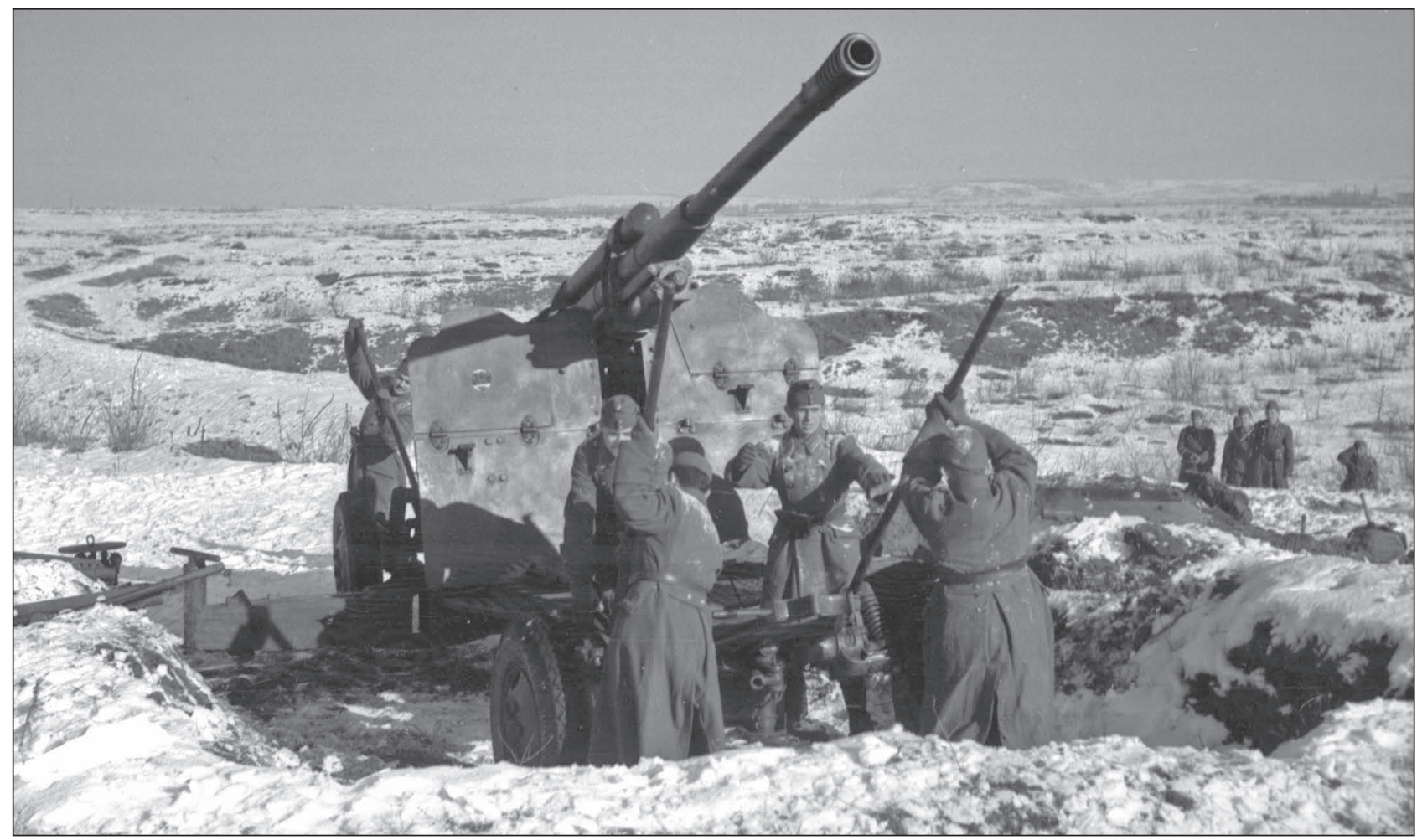

ÖSSZEFOGLALÁS: A szerzők ismertetik a „Csatti” névre keresztelt - hagyományőrzési célokra felújított - 85 mm-es 1939M 52K 8,5/8,8 Flak 39(r) közepes légvédelmi ágyú történetét. Visszatekintenek az ágyú fejlesztésének és gyártásának előzményeire, valamint felidézik a II. világháború hadszínterein, különösen a Magyarországon történt alkalmazását. Bemutatják a Magyar Tartalékosok Szövetsége (MATASZ) hagyományőrzőinek áldozatos munkáját, amellyel a légvédelmi ágyú egy leselejtezett példányát működőképes állapotba hozták.

KULCSSZAVAK: 85 mm-es 1939M légvédelmi ágyú, „Csatti”, MATASZ, II. világháború, lőelemképző
ABSTRACT: The authors present the history of the $85 \mathrm{~mm} 1939 \mathrm{M} 52 \mathrm{~K}(8.5 /$ 8.8 Flak 39 ( $r$ ) medium air defense gun, which has been renamed the "Csatti" and has been refurbished for traditional purposes. They look back at the history of cannon development and production, and recall on the battlefields of World War II, especially in Hungary. They present the sacrificial work of the traditionalists of the Association of Hungarian Reserves in bringing a discarded weapon to working condition.

KEY WORDS: 85 mm 1939M anti-aircraft gun, "Csatti", MATASZ, II. world war, ammunitio

\footnotetext{
* Ezredes, MH Modernizációs Intézet Innovációs Igazgatóság, igazgató. ORCID: 0000-0003-0449-7678

** Honvédelmi alkalmazott MH BHD 32 NHD. ORCID:0000-0003-4925-4293
} 


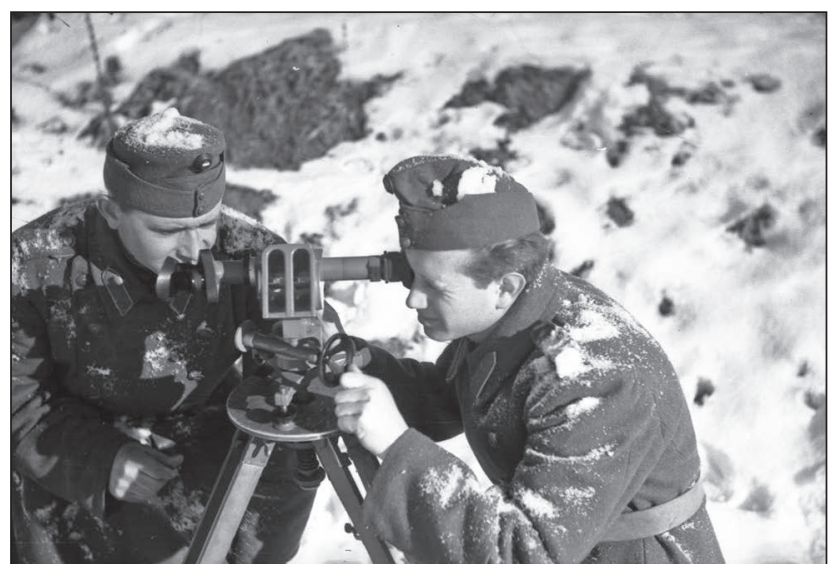

2. ábra. Irányzó-gyakorló múszer használata 1948-1950 (Fotó: HM HIM, MNN1041-5)

Bofors gépágyú alsó talpához hasonló kéttengelyes futóművel szerelték fel. (A Bofors hátsó futóműve már rendelkezett a hátsó kerekeit fékező dobfékkel.) A lövegről kivezetett fékkötelet a vontatón ülő egyik kezelő kézi erővel müködtette. Ezen a talpon a légvédelmi ágyút, - a tengelyeket átbillentő vasrudak segítségével - kézi erővel, $180^{\circ}$ kal el lehet fordítani, amitől a löveg talpaira leereszkedik. Az alsó talpat a háború időszakában egyszerűsítették, a rugókat függőlegesre cserélték, és a talp préselt elemeit már közönséges $C$ profilú acélgerendákból gyártották. A fegyver kezelése egyszerű. Hátránya azonban, hogy tüzeléskor a 4 db kerék az ágyú körüli személyi mozgást akadályozhatta, kétségtelen előnye viszont, hogy így gyorsabban lehetett tüzelőállást váltani.

Minden bizonnyal Loginov tervezőirodája is figyelemmel kísérte a német Flak 18-as 8,8 cm-es légvédelmi ágyú fejlesztését, amelynek eredményeként már 1936-ban megjelent a 8,8 cm-es Flak 36, amelyet a Flak 37 és a 41 típusok követtek. Szovjet-Oroszország és Németország között az 1920-as, '30-as években igen intenzív ipari, kutatás-fejlesztési együttmúködés zajlott. Ennek keretében például a német Junkers Flugzeug- und Motorenwerke AG repülőgépgyártási programot folytatott Oroszországban, ahol gyárat is létesítettek, és repülőgéplicenceket adtak át az oroszoknak. Ugyanabban az időben a Rheinmetall AG a 36 mm-es könnyű páncéltörő ágyú licencét átengedte a Szovjetuniónak. A német fejlesztéshez hasonlóan 1939-re elkészült a 85 mm-es 39M (52 K) légvédelmi ágyú, amely a

3. ábra. Tüzéravatás Győrben, az MH 12. Arrabona Légvédelmi Rakétaezred alakulóterén, 2018. december 4-én (Forrás: MATASZ archív)

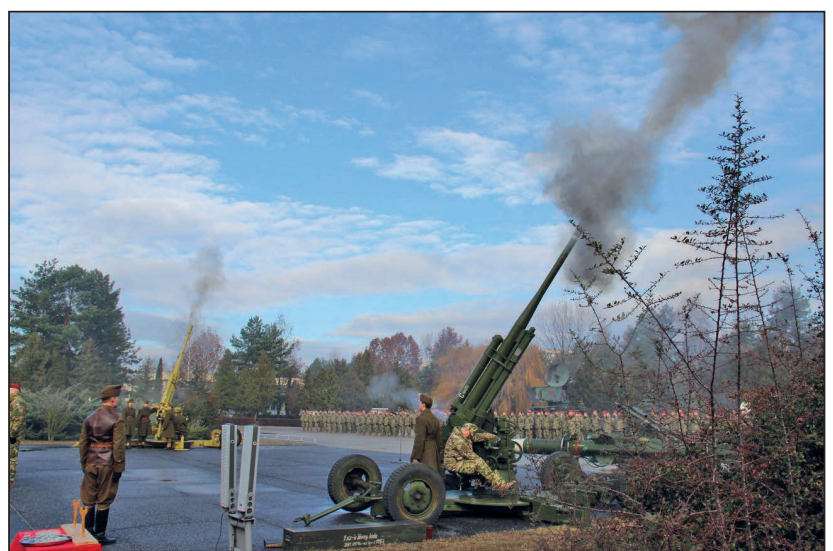

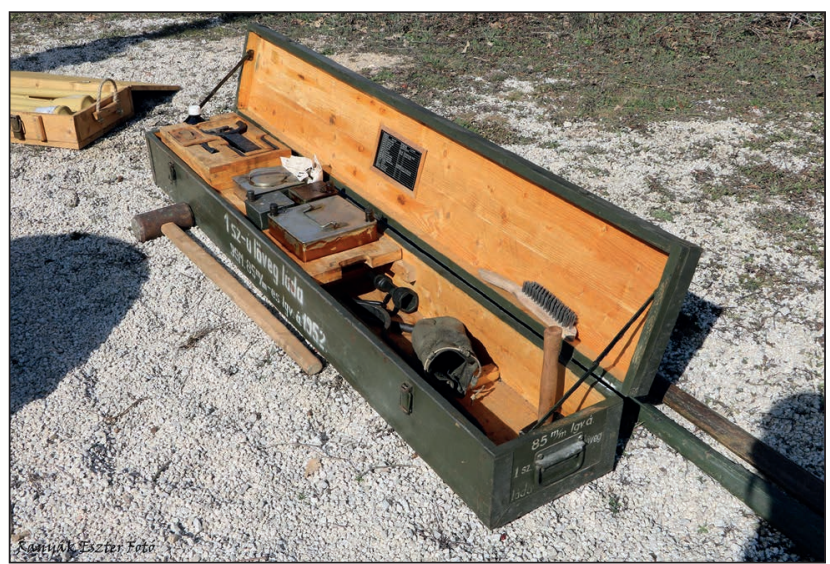

4. ábra. 1. számú egységfelszerelés-láda (Fotó: Ranyák Eszter)

II. világháború végéig a szovjet légvédelem meghatározó, korszerű, és egyben ikonikus lövegtípusa lett. Az ágyút már felszerelték elektromos jelfogórendszerrel, amely a PUAZO mechanikus lőelemképző által kiszámolt oldal-, magassági és gyújtóadatait késedelem nélkül tudta elektromos úton venni. A csövet ellátták csőszájfékkel. A csőfarba függőleges mozgású, félautomata ékzárat építettek be. Az első lövés után a félautomata ékzár a hátrasikláskor kinyílt, az üres hüvelyt kivetette, a betöltéskor pedig a zárcsukó rugó bezárta azt. A hidro-pneumatikus léghelyretoló a cső fölött, a hidraulikus fék pedig a cső alatt, az ún. bölcsőben helyezkedett el. A szovjet 52K löveg és a német Flak 18/36 hasonlósága - az alsó talptól eltekintve - szembetűnő. A két kiegyensúlyozó rugót a Flak 18/36-tól eltérően nem elöl vízszintesen, hanem a csőfar alatt, majdnem függőlegesen helyezték el. A fenti löveg modernebb váltótípusán, a 100 mm-es KS-19-es légvédelmi ágyún a kiegyensúlyozó szerkezet már szintén előre került.

E lövegeknek fontos szerepük volt az 1941. évi moszkvai csatában, ahol a várost védő szovjet légvédelmi tüzérek ezekkel az ágyúkkal sikeresen vették fel a harcot az előrenyomuló német harckocsikkal.

1941-ben a németek több száz 31M, 38M és 39M légvédelmi ágyút zsákmányoltak, amelyeket a nagy darabszámra való tekintettel a hátországi légvédelemben rendszeresítettek. A 85 mm-es lövegeket felfúrták $8,8 \mathrm{~cm}$-esre és a korábbi szovjet jelfogókat német gyártmányú, váltóáramú típusra cserélték. Ezek az ágyúk a 8,5/8,8 Flak 39(r) jelzést kapták. Az ágyú harcászati müszaki adatai kis mértékben romlottak az ürméret megváltoztatása következtében.

A Magyar Királyi Honvédség a németektől 1943-ban 90 db 39M légvédelmi löveget kapott [1], amelyeket elsősorban Budapest légterének védelme érdekében vetettek be. Több fénykép is fennmaradt, amelyeken az Erzsébet és a Lánchíd budai hídfőinél a hidakat biztosítják, valamint egy löveg a Horthy Miklós körtéren (ma: Móricz Zsigmond körtér) volt harcállásban 1945 januárjában.

Ezeket a lövegeket a város körül körben helyezték el, úgy, hogy a kilövést semmi se zavarja, és kezelőik szabad rálátással rendelkezzenek a látóhatárra. Budapest bekerítése előtt, az 1943-ban kapott 3 üteg eredeti német 8,8 cm Flak 37 löveget, szállító és vontató járműveik segítségével hátra vonták. A felfúrt $85 \mathrm{~mm}$-es szovjet lövegeket objektumvédelemre szánták, de kiszolgáló járművekkel alig rendelkeztek. Ezért csak néhány üteg lövegei kerültek a város belső részébe, elsősorban utcai erődítések támogatására. A harceszközök mozgatását főként traktorokkal és teherautókkal oldották meg. (A hadtörténeti archívumok rendelkeznek néhány archív fényképfelvétellel a városba 


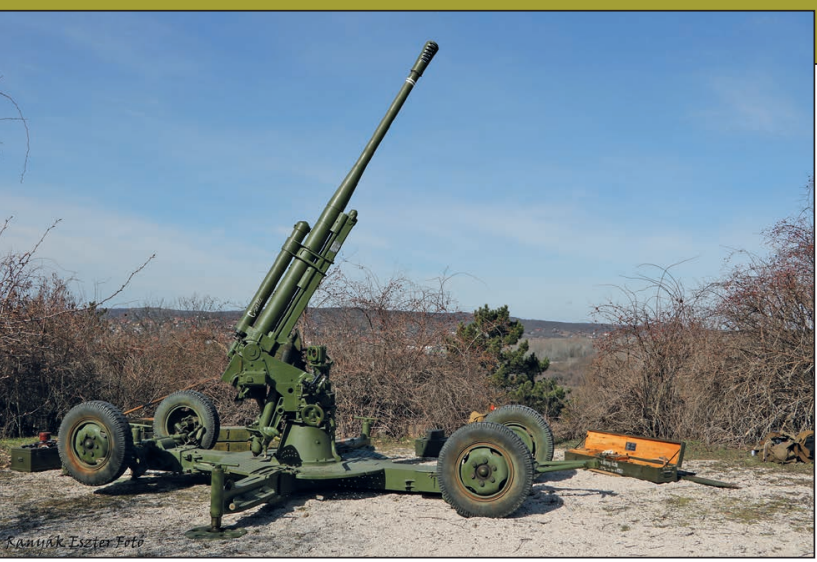

5. ábra. A hagyományőrzők légvédelmi ágyúját gyakran alkalmazzák kellékként filmforgatásokon. A fotó egy jelenetben, „tüzelöállásban” örökítette meg „Csatti”-t

(Fotó: Ranyák Eszter)

telepített lövegekről.) A többi löveg az eredeti tüzelőállásból lőtte a szovjet erőket. Amint a frontvonal elérte a Magyar Királyi Honvédség Budapest környékére telepített légvédelmi lövegeinek vonalát, a kezelők a lövegeket felrobbantották, és visszavonultak a belvárosba. A lövegek darabszáma - a többi rendszerben lévő légvédelmi ágyú darabszámának ismeretében - nem lebecsülendő. Ezek az ágyúk a kezelők körében népszerűek voltak, hiszen tömegük a német lövegeknél jóval kisebb volt, és mozgatásukat is lényegesen egyszerübben oldották meg.

1945 után az 1948-as átfegyverzési program keretében Magyarország a többi szovjet haditechnikai eszközzel együtt megvásárolta (az akkorra már elavult) $85 \mathrm{~mm}$-es 1939M légvédelmi ágyú licencét is. A lövegeket Diósgyőrben (Miskolci Nehézszerszám Gépgyár Nemzeti Vállalat, fedőszáma: 11) az 1950-es évek közepéig több mint 1000 példányban gyártották [10] (az ismert gyári azonosító számok alapján), noha a szovjetek 1947-től már áttértek a 100 mm-es KS 19 légvédelmi ágyúk gyártására.

$A z$ '50-es évek végén a típust teljesen kivonták a hazai légvédelemből, csak 15 példányt tartottak meg a protokolláris díszlövések végrehajtására. Az április 4-i díszszemlék ${ }^{2}$ elengedhetetlen része volt a díszlövés, ahol 12 ágyús díszüteg váltotta ki az össztüzeket, és további 3 ágyú tartalékként állt rendelkezésre az ócsai bázison. A kezelőszemélyzetet minden alkalommal a Zalka Máté Katonai Műszaki Főiskola légvédelmi tüzér hallgatói adták. Az ágyúkra (valószínűleg 1980-ban) központilag vezérelhető elektromos elsütőrendszert szereltek. A felszerelt mágnesek miatt azonban a csöveket már nem lehetett teljesen felemelni. A kézi elsütés lehetősége továbbra is megmaradt, az ismétlő-felhúzó karokat azonban eltávolították. Az egyetlen

6. ábra. Légvédelmi ágyú hagyományőrző kezelőszemélyzettel a Pákozdi Katonai Emlékparkban (Fotó: Ranyák Eszter)

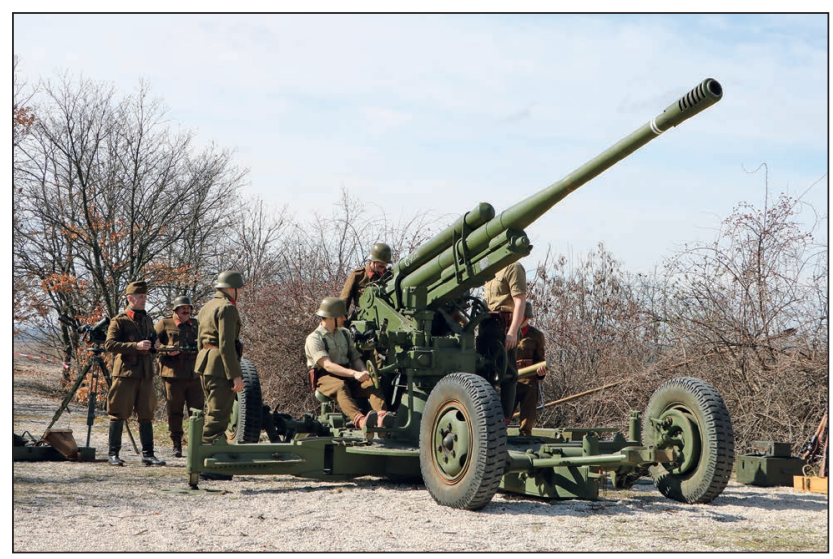

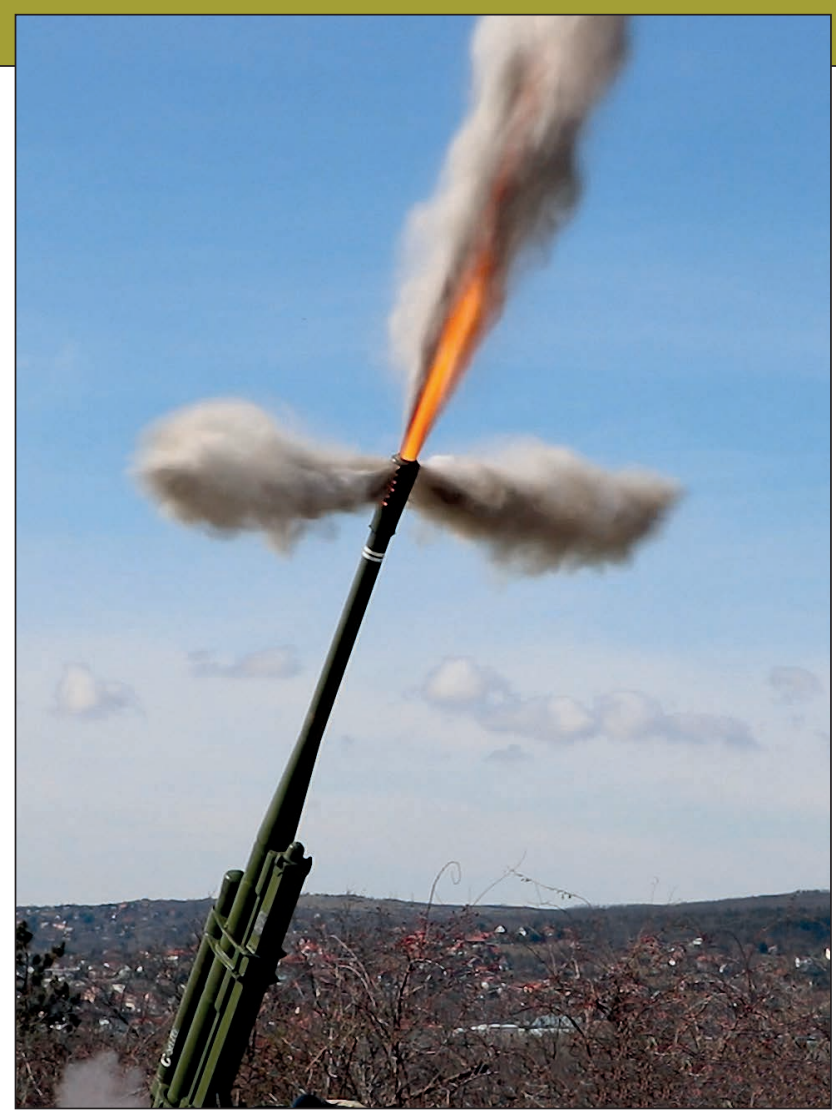

7. ábra. Torkolattǔz speciális pirotechnikai töltettel (Fotó: Ranyák Eszter)

fennmaradt lövegkönyv tanúsága szerint az utolsó díszlövésekre 1988. április 4-én került sor. Ekkor 71 díszlövést adtak le a No.: 388. számú löveggel. A lövegkönyv egyik érdekessége, hogy az 1952. évi gyártási év és 1958. január 20-a között semmilyen adatot sem vezettek. Ennek oka az lehet, hogy 1956-ban sok más eszközzel együtt ezt a löveget is őrizetlenül hagyták, és az eredeti lövegkönyve ebben az időszakban elveszett. Az okmányt 1958-ban pótolták, de ebbe a lövegkönyvbe éles lövéseket már nem vezettek.

A löveg mindegyik változatából időzíthető gyújtóval szerelt légvédelmi repeszgránátot, repesz-romboló gránátot, különböző páncéltörő, világító és propaganda célú lövedékeket lehetett tüzelni. A II. világháborúban a $85 \mathrm{~mm}$-es légvédelmi-repeszgránátokat a T-5-M lőporkorongos időzítőgyújtóval szerelték, sőt az űrméretes pácéltörő lövedék mellett már használtak ürméret alatti lövedékeket is. A lövedék a hüvellyel egybeszerelt, ún. egyesített lőszer volt. A magyar lőszeres ládákba $3 \mathrm{db}$, a szovjetbe pedig $4 \mathrm{db}$ lőszert málháztak.

2016-ban a Magyar Tartalékosok Szövetsége (MATASZ) hagyományőrzői a fent említett díszlövő légvédelmi ágyúk egyikét a honvédségi inkurrencia kiárusításából megvásárolta. Néhány hónap alatt - Jásdi Balázs vezetésével és Papp János zászlós, egykori lövegtechnikus segítségével - saját kezűleg felújították az eszközt, és a hatástalanítást hivatalos technológiai utasítás szerint végrehajtották. A felújításnak és átalakításnak köszönhetően a löveg ismét alkalmassá vált díszlövések leadására. Az új funkcióval felruházott löveget a MATASZ hagyományőrző profiljaihoz igazodva tudják használni II. világháborút és 1956-os forradalmat felidéző bemutatókon, továbbá filmforgatásokon szovjet, illetve német szerepekben is. A tartalékosok hagyományőrző csapata ennek megfelelően rendelkezik 1956-os és II. világháborús magyar, szovjet és német egyenruházattal is. A háború után rendszeresített lövegpajzsot a felújítás során eltávolították, mivel a hagyományőrzők az 1943. évi 
1. táblázat. Az 1939M (52K) 85 mm-es löveg és a 8,5/8,8 Flak 39(r) átalakított löveg adatai (A szerzők szerkesztése a [1] [7] [8] [9] alapján)

\begin{tabular}{|c|c|c|}
\hline & $1939 \mathrm{M}(52 \mathrm{~K}) 85 \mathrm{~mm}$ & $8,5 / 8,8$ Flak 39(r) \\
\hline Csőhosszúság & $4692 \mathrm{~mm}$ & $4692 \mathrm{~mm}$ \\
\hline Csőhosszúság kaliberben & 55,2 & 53,3 \\
\hline Huzagolás & állandó & emelkedő \\
\hline Huzagolás hosszúsága & $3496 \mathrm{~mm}$ & $3496 \mathrm{~mm}$ \\
\hline Barázdák száma & 24 & 32 \\
\hline Tömeg tüzelőállásban & $4500 \mathrm{~kg}$ & $4300 \mathrm{~kg}$ \\
\hline Tömege szállításkor & $4500 \mathrm{~kg}$ & $4500 \mathrm{~kg}$ \\
\hline Csőtengely magassága vízszintes csőállásnál & $1450 \mathrm{~mm}$ & $1450 \mathrm{~mm}$ \\
\hline Csőemelkedés & $-3-+80^{\circ}$ & $-3-+80^{\circ}$ \\
\hline Lövedék kezdősebessége & $800 \mathrm{~m} / \mathrm{s}$ & $790 \mathrm{~m} / \mathrm{s}$ \\
\hline Legnagyobb lőtávolság & $15500 \mathrm{~m}$ & $14400 \mathrm{~m}$ \\
\hline Legnagyobb tüzelési magasság & $10500 \mathrm{~m}$ & $10000 \mathrm{~m}$ \\
\hline A teljes lőszer tömege (légvédelmi repesz) & $15,8 \mathrm{~kg}$ & $14,7 \mathrm{~kg}$ \\
\hline Lövedék tömege (légvédelmi repeszgránát) & $9,62 \mathrm{~kg}$ & $9,099 \mathrm{~kg}$ \\
\hline Lövedék robbanótöltet (légvédelmi repesz) & $0,63 \mathrm{~kg}$ & $0,9 \mathrm{~kg}$ \\
\hline Kilövőtöltet (hajítótöltet) & $2,6 \mathrm{~kg}$ & $2,7 \mathrm{~kg}$ \\
\hline
\end{tabular}

Szovjet forrás szerint az eredeti 85 mm-es légvédelmi repeszgránátok kezdősebessége $780 \mathrm{~m} / \mathrm{s}$.

állapot bemutatására törekedtek. Az ágyún sikerült helyreállítani a műszereket is, és egy gyűjtőtől optikai irányzékot is beszereztek hozzá.

Egy évvel később egy eredeti egységfelszereléssel és az eredeti működőképes világítóberendezés-készlettel gyarapodott a löveget kiegészítő eszközök köre. Néhány üteg és ezred egységfelszerelés-ládát és $20 \mathrm{db}$ lőszeresládát is sikerült beszerezni. Eredeti, 4 m-es távmérő nem található az elérhető kiegészítő eszközök között, csere során azonban sikerült beszerezni egy ahhoz nagyon hasonló, 3 m-es műszert. A szakemberek jelenleg egy GAMMA-Juhász féle, II. világháborús lőelemképző müszer 1:1 méretarányú fémépítésű működő maketten dolgoznak. A céljuk az, hogy a lőelemképzőt elektromosan összekössék a löveg műszereivel, így a bemutatókon a lőelemképző és a löveg együtt tudjon dolgozni.

A fenti eszköz a jelenlegi állapotában és felszereltségével nemzetközi szinten is különleges értéket képvisel. Az ágyút a hagyományőrzők vezérlövegüknek tekintik, és a harceszközt egykori barátjukról, segítőjükről, Kovács László nyá. ezredesről, becenevén Csatti-ról nevezték el. A hagyományőrőzök felújított légvédelmi lövege „szolgálatot teljesített" többek között a budapesti Hősök terén, több filmben is fontos kellékként vonult fel, és különböző rendezvények fő látványossága volt.

A győri MH 12. Arrabona Légvédelmi Rakétaezred rendezvényeinek - a tüzérségi fegyvernem hagyományainak legendás és működőképes képviselőjeként - visszatérő közreműködője.

Az ágyú „beavató” (jelképes névadó) ünnepségét 2016 áprilisában, Pákozdon, a Katonai Emlékparkban tartották. A rendezvényen jelen volt Könczöl Ferenc ezredes, Tömböl László nyá. vezérezredes és Kókai Rita, Gyermely község polgármestere. [6]

A közelmúltban a MATASZ hagyományőrzői egy újabb 85-öst is beszereztek, ennek felújításában a debreceni Kratochvil Károly Honvéd Középiskola és Kollégium hallgatói is közreműködtek. A 2. löveg kezelőszemélyzetét is a honvéd középiskola hallagatói adják, így a jövő katonái is megjelennek a bemutatókon.

Az immáron polgári célra átalakított légvédelmi ágyú jelenlegi állapotában kiválóan alkalmas arra, hogy hiteles
II. világháborús magyar légvédelmi tüzérséget dinamikus és statikus módon a hagyományőrző katonák megjelenítsék.

\section{HIVATKOZOTT IRODALOM}

[1] Barczy Zoltán, Sárhidai Gyula, A Magyar Királyi Honvédség Légvédelme Budapest: Zrínyi Kiadó 2010;

[2] Lövegkönyv, 388.sz. ágyú;

[3] Schmitt, Günter, Junkers und seine Flugzeuge transpress Berlin: VEB Verlag für Verkehrswesen, 1986;

[4] Zygankow, Iwan Semjonowitsch - Sossulin, Jewgeni Alexandrowitsch, Geschütze, Granatwerfer, Geschoßwerfer Berlin: Militärverlag DDR, 1981;

[5] Pataj, Stefan, Artyleria Ladowa 1871-1970 Varsó: Wyd. Most, 1975;

[6] Kálmánfi Gábor, „Nevet kapott az ágyú” Honvédelem.hu, 2016. 4. 11. https://honvedelem.hu/galeriak/ nevet-kapott-az-agyu.html (Letöltve: 2021.5.2.);

[7] TM E9-369A German 88-MM Antiaircraft Gun Material War Department (USA), 1943;

[8] Szűcs László, „Tíz kevésbé ismert tény a Magyar Néphadseregről” Honvédelem.hu, 2013.9.28., https://honvedelem.hu/hatter/multidezo/tiz-kevesbekozismert-teny-a-magyar-nephadseregrol.html (Letöltve: 2021.5.2);

[9] „TÜFE/136 Lőszer Anyagismeret”, Honvédelmi Minisztérium kiadása, 1972.

[10] Dobrossy István (szerk.), Diósgyőri Gépgyár történetéhez Miskolc: 2009, 100. p.

\section{JEGYZETEK}

1 Mikhail Nyikolajevics Loginov orosz mérnök (1903-1940) a kalinyingrádi (Moszkvai terület) 8. Kalinin Ágyúgyár tervezőirodájának vezetőjeként számos páncéltörő, légvédelemi és más típusú tüzérség eszköz tervezésében vett részt (a szerk.)

2 A díszszemle a korabeli terminológia szerint „hazánk felszabadulásának" nevezett ünnepen rendezett katonai felvonulás, technikai bemutató volt. A díszszemléket 1948-1965 között évente, 1965-1985 között pedig ötévente rendezték meg (a szerk.). 